indicated by the very small operculigerous disk on the upper surface of the hind part of the foot.

Dall * has shown that with regard to $V$. ampullacea, an allied form from the Ochotsk Sea, \&c., the operculum is indifferently present or wanting. It may therefore be the same with the present form.

The shell of this species differs from that of $V$. ampullacea in several points. It is usually thinner, has a deeper siphonal notch, a more acuminate spire, a non-canaliculate suture, and a more velvety epidermis; and adult specimens are usually larger than any examples of $V$. ampullacea that I have ever seen. The largest specimen in the Museum is 53 millim. long, whilst the finest example of the Ochotsk species has only a length of 46 . The record of this species at Loo-Choo is interesting, as showing how far south species essentially of boreal type may be expected to extend.

XLIX.-Descriptions of somenew Genera and Species of Curculionidre, mostly Asiatic.-Part IV. By Francis P. Pascoe, F.L.S. \&c.

BRACHYDERINж.

Dermatodes mirandus.

\section{OTIORHYNCHIN Æ.}

Episomus gemmeus.

uniformis.

- laticollis.

HYLOBIINA.

Hylobius arrogans.

- desuetus.

- pumilus.

- clathratus.

Dirodes, n. g.

_ russatus.

Molytinæx.

Euthycus incisus.
TANYRHYNCHIN E.

Exætoderes, n. g.

— scabripennis.

\section{ALCIDIN $\pi$.}

Alcides gallus.

— tetanicus.

- censorius.

vestitus.

— nitidus.

- geminatus.

— Oberthürii.

- collaris.

\section{BARIDINAE}

Baris cælestis. - eburifera.

Acythopeus genuinus.

funereus.

Lystrus longimanus.

* American Journ. Conch. vol. vii. p. 105. 


\section{Dermatodes mirandus.}

D. ovatus, squamis læte viridibus, aliis maculatim aureo-nitidis, tectus; rostro capite continuato; antennis funiculo clavaque nigris. Long. $5 \frac{1}{2}$ lin. (rostr. incl.).

Hab. Zanzibar.

Ovate, densely covered with rich glossy green scales, with golden scales interspersed; head not broader than the rostrum and without the groove separating them; antennæwith the scape passing behind the eye, the funicle filiform, black, the club also black, but covered with a whitish pubescence; prothorax moderately transverse, broad at the base, the sides slightly rounded; scutellum small, distinct; elytra convex, gradually narrowing towards the apex, striate-punctate, striæ very shallow; corbels of the posterior tibir densely covered with whitish hairs ; claw-joint elongate.

A richly coloured species, with an exceptionally long scape; the length, however, varies according to the species; in some it does not or scarcely attains the eye, $D$. ccesicollis for example; in others it impinges more or less on it.

\section{Episomus gemmeus.}

E. oblongo-ovatus, niger, squamis viridi-aureis vestitus; antennis funiculo tenuato, clava pyriforme sed apice acuta ; capite rostroque linea angusta longitudinaliter impresso. Long. $6 \frac{1}{2}$ lin. (rostr. incl.).

\section{$H a b$. Sumatra.}

Oblong, ovate, black, clothed above, but not closely, with golden-green scales, beneath, and especially the femora, with close-set, mostly paler scales; antennæ with a comparatively slender funicle, its second joint elongate, the club pyriform, with the apex somewhat produced and pointed; prothorax with slightly impressed transverse grooves at the sides, and with two black stripes on the disk; elytra punctured, the scales confined to the punctures.

The species of Episomus are so variable in coloration that very little reliance can be placed on it to differentiate them; the sculpture also is not very definite. The specimen here described has unusually lustrous scales, a comparatively slender funicle, a club tapering at the base, with a somewhat produced and pointed apex, \&c. It may possibly be $E$. gracilicornis, very shortly described by Ritsema, but which is said by Chevrolat not to be a true Episomus.

\section{Episomus uniformis.}

E. ovatus, omnino griseo-squamosus; antennis funiculo crasso, 
articulis $3^{\circ}-6^{\mathrm{m}}$ brevissimis, septimo elongato, cylindrico, nigro ; rostro quam caput ad apicem latiore; prothorace flexuoso-sulcato. Long. $5 \frac{1}{2}-7$ lin.

Hab. Andaman.

Ovate, entirely covered with brownish-grey scales; antennæ rather slender, black, the third to the sixth joint very short, the seventh elongate, cylindrical, and closely united to the short club; rostrum somewhat broader at the apex than the head; prothorax with irregular, flexuous, transverse grooves; elytra striate-punctate, interstices narrow, slightly raised, each elytron with a black spot posteriorly; body beneath and legs closely covered with small pale grey scales and a few markedly larger ones intermixed on the former, the legs with a few scattered setæ.

A uniformly grey or brownish-grey species, with the third to the sixth joint of the funicle markedly short, the seventh elongate, \&c.

\section{Episomus laticollis.}

$E$. ovatus, obscure griseo-squamosus; prothorace valde transverso, utrinque rotundato, sulcis tribus impresso ; elytris striato-punctatis, interstitiis setigeris. Long. 4 lin.

\section{Hab. Pachebon.}

Ovate, covered with dull greyish scales; antennæ with a short, nearly straight scape; funicle moderately long, the seventh joint closely united to the short ovate club; head and rostrum broad, with a continuous median groove and a shallower one on each side; prothorax very transverse, rounded at the sides, slightly pitted, and with three shallow grooves towards the base; elytra striate-punctate, the interstices slightly raised, each with a row of pale setæ; body beneath and legs with greyish scales and setæ.

Allied to E. iconicus, in which, as in the above, the scutellum is apparently absent; it has, however, inter alia, a shorter and much broader prothorax; the upper edge of the scape is nearly straight.

\section{Hylobius arrogans.}

$H$. robustus, fuscus, opacus, squamulis setulisque adspersus ; rostro incrassato, grosse punctato; prothorace rugoso-granulato, basi latiore; elytris prothorace multo latioribus, seriatim punctatis, punctis mediocribus, quadratis; apice conjunctim rotundato. Long. 8 lin.

$H a b$. Sumatra.

Robust, dull brown, with a scattered scaly indumentum 
mixed with small setæ; rostrum stout, with four raised line, the outer flexuous, the front coarsely punctured ; antennæ with the first joint of the funicle twice as long as the second ; prothorax not longer than broad, rounded at the sides, but expanding at the base, the disk roughly granulate; scutellum cordiform; elytra very broad at the base, gradually narrower to the broadly rounded apex, seriate-punctate, punctures middle-sized, quadrate; body beneath with scattered punctures, each bearing a brownish-yellow seta, and more numerous at the sides of the abdominal segments; legs sparsely setulose; femora strongly toothed; fore tibiæ slightly curved.

The groove in front of the eye-one of the characters of Hylobius according to Lacordaire-is short and not well limited, and the posterior callus on each elytron is nearly obsolete. This species may be placed after $H$. crassirostris.

\section{Hylobius desuetus.}

$H$. robustus, fuscus, subnitidus, setulis fulvidis adspersus; rostro tenuato ; prothorace granulis conjunctis setigeris munito ; elytris striato-punctatis, interstitiis parte basali granulatis. Long. 6-7 lin.

Hab. Siam, Sarawak.

Robust, rather glossy brown, with numerous small fulvous setæ; rostrum comparatively slender, with three principal grooves marked with coarse oblong punctures; antennæ pitchy; prothorax with the sides nearly parallel posteriorly, the disk with connected granules in oblique lines, each tipped with a curved seta; scutellum triangular; elytra considerably broader at the base than the prothorax, striate-punctate, the punctures oblong, large, approximate, interstices not well marked, those on the basal half dotted with small glossy granules, each tipped with a procumbent seta; femora obtusely toothed.

The more slender rostrum and the less convex elytra, with their interstices granulate, are the leading differential characters of this species. In this and the preceding species there is a tendency of the setulæ to a closer approximation on the elytra behind the middle, forming a somewhat indistinct band.

\section{Hylobius pumilus.}

$H$. oblongus, fusco-ferrugineus, nitidus ; antennis, femoribus basi, tibiis dimidio apicali tarsisque rufulis; rostro incrassato, grosse punctato; femoribus dente acuto armatis. Long. 3 lin.

Hab. Sarawak. 
Oblong, dark ferruginous, glossy, antennæ, femora at the base, apical half of the tibir and tarsi reddish ; rostrum stout, strongly marked throughout with oblong punctures; antennæ slender; prothorax without ocular lobes, slightly rounded at the sides, the disk with large, irregular, confluent granules; scutellum triangular; elytra somewhat broader posteriorly, flattish above, striate-punctate, punctures large, approximate, the interstices flat; second abdominal segment as long as the two next together; femora with an acute tooth.

A small flattish species, differing from the genuine Hylobii in having no ocular lobes; but they are very slight in $H$. papulosus, after which it may be placed.

\section{Hylobius clathraius.}

$H$. oblongus, niger, parum nitidus, sparse setulosus; rostro subtenuato, sex-sulcato, sulcis intermediis basi approximatis; prothorace oblongo, grosse granulato; elytris punctis quadratis magnis instructis, apicibus paulo divaricatis. Long. 6 lin.

\section{Hab. India.}

Oblong, black, slightly glossy, with small pale scattered setæ, more condensed posteriorly; rostrum rather slender, coarsely punctured, with six irregular grooves in front, the two intermediate approximate at the base; antennæ with the two basal joints of the funicle equal; prothorax oblong, a little contracted at the base, coarsely granulate; elytra subcylindrical, the apices slightly divaricate, seriate-punctate, the punctures large, quadrate, the alternate interstices prominent, the intermediate interstices represented here and there by finely raised lines; body beneath sparsely punctured; femora toothed; tibiæ nearly entire.

A very coarsely sculptured species allied to $H$. rusticus, but, inter alia, with the posterior callus on each elytron strongly produced; the punctuation of the elytra is also different.

\section{Dirodes.}

Hylobio affinis. Scrobes valde obliquæ, infra rostrum conniventes. Oculi laterales, transversi, fortiter granulati. Abdomen sutura prima obsoleta. Unguiculi connati.

The claws being united at the base separates Lacordaire's "Pacholenides" (a group of his "tribu Hylobiides") from his group of true "Hylobiides;" but the shorter metasternum and the facies seem to me to indicate that the affinities of this genus are nevertheless with Hylobius rather than with either 
of the two genera of "Pacholenides" enumerated by Lacordaire.

\section{Dirodes russatus.}

$D$. subcylindricus, rufo-brunneus, sparse setosulus ; antennis brevibus; femora dentata ; tibiæ anticæ curvatæ. Long. $4 \frac{1}{2}$ lin.

Hab. Sumatra.

Subcylindrical, reddish brown, sparingly setulose; head convex in front; rostrum stout, curved, as long as the prothorax, thinly punctured; scrobes comparatively short, connivent beneath ; antennæ short ; first joint of the funicle subglobose, second rather longer, the rest transverse, gradually broadening into the ovate club; prothorax subtransverse, roughly granulate, ocular lobes feeble; scutellum raised; elytra nearly cylindrical, broader than the prothorax, the base shortly and abruptly sloping forwards, striate-punctate, punctures oblong, the interstices convex, finely granulate, posterior callus prominent; prosternum not emarginate; metasternum short; abdomen with the first suture obliterated, the conjoined segments very large and convex; femora with an acute tooth beneath; fore tibiæ short and curved; tarsi gradually broader to the third joint, which is strongly lobed, fourth joint elongate, its claws united at the base.

\section{Euthycus incisus.}

E. oblongus, níger; prothorace utrinque apicem versus linea profunda impressa instructo, disco fortiter bicanaliculato; elytris earinis alte elevatis munitis. Long. 6 lin.

$H a b$. India.

Oblong, black; rostrum rather long, stout, with numerous coarse, closely-set punctures; antennæ ferruginous, second joint of the funicle nearly twice as long as the first; club pubescent; prothorax longer than broad, rugose, having on each side a deeply incised vertical line near the apex, disk with two regular longitudinal grooves or canals; no scutellum; elytra twice as long as the prothorax, broadly rounded at the apex, the sutural margin raised as well as two lines on each elytron, which unite posteriorly and are more or less covered with short, yellowish, erect setæ, the intervals with coarse oblong punctures ; legs moderately long; femora toothed; posterior tibiæ elongate, curved.

In size and outline like Plinthus porcatus, but with a peculiarly sculptured prothorax \&c. I have placed it with Euthycus rather than with Plinthus, on account of the oblique Ann. \& Mag. N. Hist. Ser. 5. Vol. xx. 
scrobes directed to the lower margin of the eye. The type is $\boldsymbol{E}$. macilentus (Ann. Mus. Civico de Genova, ser. 2, vol. ii. p. 220 , tav. i. fig. 6 ).

\section{EXATODERES.}

Caput latum ; rostrum perbreve, capite angustius; scrobes ante oculos desinentes. Oculi rotundati, grosse granulati; scapus antennarum pone oculum extensus. Prothorax subtransversus, lobis ocularibus nullis. Elytra convexa, prothoracis basi ibi haud latiora. Femora mutica; tibice inermes; tarsi tenues, articulo penultimo haud lobato. Pectus breve. Episterna metathoracica elytris cælata, segmentum basale abdominis vix ampliatum.

This genus wants two or three of the characters assigned to the Tanyrhynchinæ by Lacordaire, notably of the rostrum and tarsi ; the former is very short and broad and the latter are nearly filiform, the claw-joint being received in a cavity of the preceding.

\section{Excetoderes scabripennis.}

$E$. subellipticus, tomento pilisque griseo-brunneis omnino tectus; elytra elongato-cordata, lineis elevatis tuberculatis munita. Long. 6 lin.

Hab. Capetown.

Clothed with a uniformly greyish tomentum and paler approximate hairs. Head broad and convex in front; rostrum much shorter and marked off by two oblique, slightly impressed lines; antennæ ferruginous, pubescent; funicle with the first joint nearly as long as the two next together; prothorax as long as broad, constricted anteriorly, the sides then rounded and covered with minute granules, each tipped with a recumbent hair, the middle with a short black line; scutellum not apparent; elytra oblong-cordate, each with seven more or less elevated tuberculate lines; tubercles small, many of them tipped with a hair much longer than those elsewhere; tibiæ straight, dilated at the apex.

\section{Alcides gallus.}

$A$. oblongus, nitide rufo-castaneus ; rostro elongato, subtiliter punctato; prothorace granulato, in medio carinula lineare munito; elytris postice gradatim angustioribus, striato-punctatis, interstitiis subtransversim impressis. Long. 4 lin.

Hab. Saylee.

Oblong, glossy reddish chestnut; rostrum slender, nearly twice as long as the prothorax, minutely punctured; antennæ 
pitchy, scape rather short, second joint of the funicle longer than the first; prothorax with darker irregular granules, the intervals with narrow silaceous scales, a narrow, raised, median line throughout; scutellum small, black; elytra gradually narrower from the base, a little depressed behind the scutellum, striate-punctate, punctures nearly contiguous, the interstices somewhat transversely impressed; body beneath and legs sparsely covered with minute silaceous scales; fore tibiæ very slightly bisulcate.

In this species there is on the prothorax a well-marked median line continuous throughout; the depression behind the scutellum on the elytra is more circumscribed than on the following species.

\section{Alcides tetanicus.}

A. oblongus, nitide rufo-castaneus, parce silaceo-setosulus; rostro valido, versus apicem latiore, tenuiter punctato ; prothorace granulato, ad apicem carinula lineare munito; elytris postice gradatim angustioribus, striato-punctatis, interstitiis subtiliter punctatis. Long. 6 lin.

\section{$H a b$. Saylee.}

Oblong, glossy reddish chestnut, sparsely covered with small silaceous setæ; rostrum stout, broader at the apex, finely punctured; antennæ rather short, second joint of the funicle not longer than the first; prothorax slightly convex, granulate, a raised line at the apical half; scutellum black; elytra gradually narrower from the base, the anterior part depressed, linearly punctured, punctures sinall, round, the interstices broad, with a few granules at the base; body beneath sparsely covered with minute silaceous scales; fore legs of moderate length, their tibiæ very slightly bisinuate; anterior coxæ approximate.

At once distinguished from the preceding by its stout rostrum ; the fore legs are comparatively short, the body at the shoulders is of considerable breadth, and the elytra towards the apex are much more markedly narrowed.

\section{Alcides censorius.}

$A$. oblongus, nigro-piceus, subtiliter parce griseo-pilosus ; rostro elongato, tenuato, parte basali solo remote punctato; funiculo articulo secundo breviusculo ; prothorace granulato ; elytris striatopunctatis, interstitiis rude granulatis. Long. 6 lin.

\section{$H a b$. Ceram.}

Oblong, pitchy black, covered with a thin greyish pilosity ; rostrum elongate, slender, the basal part only distinctly punc- 
tured; antennæ black, second joint of the funicle shorter than the first; prothorax closely granulate; scutellum roundish; elytra convex, gradually narrower from the base, the anterior part slightly depressed, striate-punctate, punctures coarse, approximate, the interstices covered with irregular granulations; body beneath rather closely covered with small whitish scales; fore legs elongate; tibiæ slightly bisinuate.

It is only under a strong lens that the real sculpture of the elytra is seen; to the naked eye they seem minutely punctured in close regular lines. So far as the facies is concerned this species may follow $A$. decurvus.

\section{Alcides vestitus.}

$A$. cylindricus, niger, plerumque dense albido-pilosus, setulis interjectis ; rostro tenuato, basi confertim punctato; prothorace granulato ; elytris modice convexis, lateribus parallelis. Long. 5 lin.

\section{Hab. Banda.}

Rather narrowly cylindrical, black, covered with large patches of a close-set whitish squamosity, studded with hairlike setæ; rostrum slender, twice as long as the prothorax, the base with crowded punctures; antennæ pitchy, second joint of the funicle longer than the first; prothorax nearly as long as broad, the middle of the disk bare and closely granulate, the sides densely covered with whitish scales; scutellum subquadrate; elytra moderately convex, parallel at the sides, on each a bare oblique stripe in the middle, the rest with a dense covering of whitish scales; body beneath densely covered with minute yellowish scales; fore tibiæ strongly bisinuate.

The close-set whitish or yellowish-white scales or squamosity, studded with hair-like setæ, nearly covering the whole upper surface of this species, will at once differentiate it from any of its congeners. In the above four species the femoral tooth is very distinctly denticulate.

\section{Alcides nitidus.}

A. oblongus, glaber, nitide chalybeatus, supra squamulis albis maculatim ornatus; rostro elongato, tenuato, fere recto, subtilissime punctato; prothorace leviter punctato; elytris punctis parvis seriatim instructis. Long. 4-5 lin.

Hab. Batchian, Waigiou.

Oblong, smooth, glossy steel-blue, more or less spotted with masses of white scales; rostrum slender, elongate, nearly straight, minutely punctured; antennæ pitchy, funicle elon- 
gate, the two basal joints equal in length; prothorax with small remote punctures; scutellum roundish; elytra seriatepunctate, punctures small, remote, the interstices broad, flattish, each elytron with a white spot near the scutellum, three or four behind the middle, or connected so as to form a band, and two near the apex; body beneath smooth, the sterna more or less covered with close-set whitish scales; legs slender; anterior tibiæ very slightly bisulcate.

One of my specimens has the three intermediate abdominal segments margined with close-set white scales and an additional white spot near the base of each elytron. This species is somewhat remarkable in having the rostrum extremely minutely punctured at the base as well as beyond to the apex.

\section{Alcides geminatus.}

$A$. oblongus, fuscus, lineis griseis e pilis condensatis ornatus ; rostro piceo, elongato, tenuato, apice dilatato; prothorace inæqualiter punctato, granulis parvis intermixtis; elytris rude striato-punctatis. Long. $3 \frac{1}{2}$ lin.

Hab. Java.

Oblong, dark brown, with a few lines of greyish hairs; rostrum pitchy, elongate, slender, much broader at the apex; antennæ ferruginous, the second joint of the funicle shorter than the first; prothorax irregularly punctured, with a few granules between the punctures, the disk with two narrow greyish stripes and one on each side; scutellum roundish; elytra nearly parallel at the sides, with linear punctured striæ, punctures subquadrate, the interstices rugose, each elytron with an elongate, oblique, slightly flexuous stripe proceeding from the shoulder, and a shorter oblique apical stripe directed towards the suture; body beneath with scattered scales, except on the sterna; anterior femora slender, their tibiæ slightly bisulcate.

Very near $A$. intrusus, but with a slender elongate rostrum, and more slender but scarcely longer antennæ, and the prothorax with two lateral instead of one median line on the disk \&e.

\section{Alcides Oberthür $\ddot{i}$.}

$A$. obovatus, fuscus, capite, rostro antennisque piceis ; elytris striatis, striis setulis silaceis repletis, interstitiis granulis nitidis planiusculis confertim instructis. Long. 4 lin.

Hab. India *.

* I owe my specimen to M. René Oberthür. The habitat given on his ticket is "Indes Orientales, Mts. Kodeicanel." I cannot tind this name in Keith Johnston's large atlas. I believe, however, that they are in Southern India. 
Obovate, brown; head, rostrum, and antennæ dark pitchy brown; rostrum stout, nearly straight, a little longer than the prothorax, remotely punctured throughout; second joint of the funicle considerably shorter than the first; prothorax with rather large, flattish, and occasionally confluent granules, the interspaces finely setulose, the sides with close-set scales, trifid at the apex; elytra gradually broader behind, striatepunctate, the striæ filled with silaceous hair-like scales, the interstices with large, flattish, approximate granules; body beneath covered with greyish scales; legs comparatively short, the tooth on the femora not denticulate.

The elytra broader behind and their striæ filled with silaceous scales, forming well-defined lines alternating with the glossy interstices, will at once differentiate this very marked species. The scutellum is not to be distinguished from the surrounding parts.

\section{Alcides collaris.}

$A$. breviter ovatus, niger, nitidus, prothorace rufo-castaneo elytrisque albo-bifasciatis ; femoribus dente parvo integro instructis. Long. $3 \frac{1}{2}$ lin.

Hab. India.

Shortly ovate, glossy black, the prothorax reddish chestnut, and the elytra with two white bands of close-set scales; rostrum stout, shorter than the prothorax, gradually broader towards the apex, not curved, and approximately punctured throughout; antennæ pitchy, short, stout, first joint of the funicle twice as long as the second; prothorax somewhat globose, with large, flattish, crowded granules, each with a minute white scale behind, the middle with a few punctures; scutellum small but distinct; elytra slightly narrower from the base, with large subapproximate punctures, the interspaces smooth, a transverse series of nearly united spots at the base, and just behind the middle a flexuous band, not meeting at the suture; body beneath glossy black, with patches of white scales; legs comparatively short; the anterior femora armed with a slender spiniform tooth, their tibiæ moderately bisinuate.

The species of Alcides here described have bifid claws and elytra not, or scarcely, broader than the prothorax; the latter more or less transverse, with the sides behind the contracted apex rounded, except at the base. In all the species of this large genus (I have about 140) the funicle is only six-jointed, and the base of the prothorax is deeply bisinuate, the scutellar lobe especially advancing considerably between the elytra. 


\section{Baris calestis.}

$B$. elliptico-ovata, læte cærulea vel violacea, antennis tarsisque nigris ; rostro modice elongato, basi constricto ; elytris profunde striatis, interstitiis planatis, uniseriatim punctatis. Long. 3 lin.

Hab. Delagoa Bay.

Elliptic-ovate, clear blue or violet, antennæ and tarsi black ; head finely punctured; rostrum rather elongate, the base compressed and coarsely punctured, beyond glossy black, with finer punctures; prothorax transverse, slightly concave, closely and coarsely punctured; scutellum equilaterally triangular, with the apex towards the prothorax; elytra narrowly striate-punctate, the striæ blackish, with greenish specks between the punctures, interstices flat, each with a row of rather marked punctures; body beneath and legs punctured, each puncture bearing a short white hair ; tarsi with the three basal joints gradually broader.

This species belongs to Schönherr's first "stirps," $i$. e. those species with stout antennæ. The colour varies a little according to the light. The form of the scutellum is peculiar.

\section{Baris eburifera.}

B. cylindrica, atra, opaca; elytris maculis sex albis basalibus munitis; rostro fortiter striato-punctato; pedibus ferrugineis. Long. $1 \frac{1}{2}$ lin.

$H a b$. India?

Cylindrical, opaque black, elytra with six spots at the base, formed of tufts of white or cream-coloured scales; rostrum stout, not longer than the prothorax, curved, closely punctured between slightly elevated longitudinal lines; antennæ ferruginous, short, stout, the funicle gradually thickening into the club; prothorax nearly as long as broad, bisinuate at the base, closely punctured; scutellum small, triangular; elytra parallel for about half their length, then gradually rounded to the apex, striate-punctate, punctures oblong or shortly linear, interstices slightly raised; legs dark ferruginous, with sparse greyish scales.

This species has lately occurred in hothouses in England, imported with orchids from India or the East. It is one of the smaller kinds, like B. morio, but peculiar for its tufts of closeset white scales on the elytra, to the naked eye resembling little ivory points.

\section{Acythopeus genuinus.}

A. ovatus, niger, opacus; rostro basi haud gibboso; prothorace 
utrinque rotundato, sat fortiter punctato, punctis inter se separatis; elytris interstitiis subtiliter granulatis. Long. $2 \frac{1}{2}$ lin.

Hab. Malaisia.

Ovate, black, opaque; rostrum not gibbous at the base, coarsely punctured, the punctures uniformly separated; antennæ black, the club ovate; prothorax transverse, rounded at the sides, not narrowed at the base, and comparatively coarsely punctured, the punctures approximating but distinctly separated; scutellum nearly round; elytra narrowly striate, the interstices flat and minutely granulate, the granules few and in a somewhat irregular line; pygidium very short; body beneath and legs sparingly punctured, each puncture with a short silver hair.

Some time ago I received several specimens of this species from G. Saunders, Esq., in whose conservatory at Tunbridge Wells they were found in the stems of certain orchids; like its congeners its habitat is probably some island of the Malay Archipelago. It differs from A. tristis (Linn. Soc. Journ. xii. p. 62 , pl. iii. fig. 2) in the form and sculpture of the prothorax, the granulate interstices of the elytra, \&c. Mr. C. Waterhouse has described another species (A. aterrimus, Ent. Month. Mag. vol. x. p. 226) closely allied to both, but differing in sculpture, the latter having the rostrum furrowed at the sides, the prothorax with glossy granules on the interspaces between the punctures, \&c.

\section{Acythopeus funereus.}

$A$. ovatus, niger, opacus; elytris basi singulatim macula parva alba notatis; rostro basi fortiter gibboso; oculis infra connexis; elytris interstitiis transversim sulcatis. Long. $2 \frac{1}{2}$ lin.

Hab. Tondano.

Ovate, black, opaque, a small white spot on each elytron at the base; rostrum compressed and strongly gibbous or raised at the base, and roughly granulate, the rest smooth, glossy black, and nearly impunctate; prothorax moderately transverse, closely punctured; scutellum indistinct; elytra narrowly striate, the interstices flat and transversely sulcate; pygidium short; body beneath and legs studded with silvery hairs.

In facies like the last, but at once differentiated by its gibbous rostrum, the eyes confluent beneath; sculpture of rostrum and elytra, \&c. The transverse grooves on the interstices of the elytra are apparently composed, at least in some places, of two partially connected punctures. 


\section{Lystrus longimanus.}

$L$. trapezoideus, fusco-niger, parum nitidus ; antennis ferrugineis ; rostro dimidio basali lineis elevatis instructo; pedibus anticis valde elongatis, tibiis eorundem fortiter arcuatis. Long. $2 \frac{1}{2}$ lin.

$H a b$. Sumatra.

Trapezoidal, brownish black, slightly glossy, antennæ ferruginous; rostrum moderately long, basal half with raised lines, the intervals punctured ; antennæ with the club as long. as the funicle; prothorax rapidly broader to the base, with close-set granules in short transverse lines ; scutellum round; elytra narrowly striate, the interstices broad, with contiguous punctures; body beneath densely covered with pale greyish scales; intermediate and posterior legs very short, ferruginous, the tibiæ of the former with a tooth on the outer edge at the base ; fore legs very long, their tibiæ strongly curved, their tarsi of moderate length.

A broader species than L. latipennis (Linn. Soc. Journ. xii. p. 44, pl. iii. fig. 1) and differently sculptured. It is possible that the remarkably long anterior legs may be a sexual distinction, at least to a certain extent.

\section{L.-On the Phylogeny and Anatomy of the Echinodermata.} By Dr. Otto HamanN*

\section{Origin of the Echinodermata.}

If we set before us the question to what group of the Metazoa, with reference to the whole of their peculiarities of organization, are the Echinodermata most nearly related, the answer will serve at the same time to throw light upon their phylogenetic origin. I have said if we take into consideration "the whole of their peculiarities of organization," and therefore the constitution of the nervous system, the bodycavity, \&c., and would thereby indicate that I must regard as failures all the attempts which look only to a single system of organs, such as has lately been made by Kleinenberg, who, by taking into consideration only the nervous system, has been led into the most wonderful speculations as to the origin

* The concluding chapter of a memoir on the Histology of the Echinodermata, translated from the 'Jenaische Zeitschrift,' Band xxi. pp. 232251. 


\section{$2 \mathrm{BHL}$ Biodiversity Heritage Library}

Pascoe, Francis P. 1887. "XLIX.-Descriptions of some new genera and species of Curculionidæ, mostly asiatic.-Part IV." The Annals and magazine of natural history; zoology, botany, and geology 20, 348-361. https://doi.org/10.1080/00222938709460076.

View This Item Online: https://www.biodiversitylibrary.org/item/95053

DOI: https://doi.org/10.1080/00222938709460076

Permalink: https://www.biodiversitylibrary.org/partpdf/68561

\section{Holding Institution}

Harvard University, Museum of Comparative Zoology, Ernst Mayr Library

\section{Sponsored by}

Harvard University, Museum of Comparative Zoology, Ernst Mayr Library

\section{Copyright \& Reuse}

Copyright Status: Public domain. The BHL considers that this work is no longer under copyright protection.

This document was created from content at the Biodiversity Heritage Library, the world's largest open access digital library for biodiversity literature and archives. Visit BHL at https://www.biodiversitylibrary.org. 